\title{
Dampak Teknologi E-Logistic SCM Terhadap Distributor Busana di Pontianak Selatan
}

\author{
Irawan Wingdes \\ Jurusan Sistem Informasi \\ STMIK Pontianak \\ Pontianak, Indonesia \\ e-mail: irawan.wingdes@gmail.com \\ Diajukan: 6 Juli 2020; Direvisi: 31 Agustus 2020; Diterima: 21 September 2020
}

\begin{abstract}
Abstrak
Supply Chain Management menjadi salah satu perkembangan inti dari aktivitas organisasi. Dalam berbagai referensi SCM, utilisasi internet dan e-logistic melalui third party logistics mendukung upaya efisiensi supply chain, tetapi berpotensi mengancam rantai distributor. Menimbang kurangnya penelitian sebelumnya di Kalimantan Barat dan Pontianak khususnya, penelitian ini berupaya menjawab pertanyaan bagaimana dampak dari perkembangan SCM dan e-logistics secara praktik dalam rantai distributor di Pontianak Selatan. Metode kualitatif dengan pertanyaan semi terstruktur diutilitasi untuk penelitian. Penelitian mengacu pada teori Protection Motivation Theory untuk membahas dampak perkembangan SCM maupun penerimaan teknologi e-logistic. Alat analisis data menggunakan NVivo 12. Hasil menunjukkan bahwa perkembangan SCM mempengaruhi bisnis distributor dan terdapat persiapan yang unik di antara distributor dalam mengatasi dampak tersebut.
\end{abstract}

Kata kunci: SCM, E-logistics, 3PL, Protection motivation theory.

\begin{abstract}
Supply Chain Management has become one of the crucial part of modern organizations value chain. Notwithstanding the concept proposes efficiency compared to traditional supply chain, the concept also proposes threats to wholesalers or distributors in a traditional distribution channel. With recent emergence of technological advancement in e-logistics, how SCM and the technology development in the area affects distributors in a supply chain are rarely researched, especially in Pontianak Selatan. The purpose of this research is to investigate the effects of SCM and e-logistic through third party logistics on distributors in a traditional apparel products supply chain. Qualitative method is utilized with protection motivation theory as guidance to answer research question. Data is analyzed with NVivo software. Results and future research are discussed further in article.
\end{abstract}

Keywords: SCM, E-logistics, 3PL, Protection motivation theory.

\section{Pendahuluan}

Supply Chain Management atau SCM menjadi salah satu aktivitas inti dari organisasi kontemporer [1]. SCM adalah manajemen kegiatan dari semua pihak yang terlibat, baik secara langsung maupun tidak langsung, dalam memenuhi kebutuhan konsumen [2]. Kegiatan-kegiatan tersebut tidak hanya terdiri dari pabrik dan pemasok, tetapi juga pihak transportasi, gudang, toko dan konsumen, termasuk pengaturan rangkaian proses, aliran uang, material, serta informasi pada berbagai tingkatan pelaku usaha. Dalam ruang lingkup organisasi individu, supply chain termasuk semua fungsi yang diperlukan dalam menerima dan memenuhi permintaan konsumen, mencakup pengembangan produk baru, pemasaran, operasi, distribusi, keuangan, sampai layanan pelanggan. Walaupun SCM saat ini menjadi bagian inti proses bisnis, diseminasi dari konsep tersebut di industri secara praktis masih jarang diteliti, terutama di negara berkembang dan khususnya di daerah Kalimantan Barat.

Chopra membagi proses yang terjadi dalam supply chain menjadi cycle view dan push/push view. Cycle view memandang proses yang terjadi dalam supply chain menjadi beberapa siklus, sedangkan pull/push view memandang proses yang terjadi menjadi reaktif (berdasarkan pesanan atau pull) atau antisipatif (antisipasi permintaan dengan menyediakan barang di inventory atau push). Perkembangan dari 
supply chain pada akhirnya akan menuju pemenuhan kebutuhan konsumen yang fokus ke arah pull atau pesanan pelanggan yang langsung diproduksi dan dikirimkan ke konsumen tanpa melalui perantara [2].

Terdapat empat klasifikasi siklus supply chain, yaitu Customer Order (konsumen dan toko fisik), Replenishment (toko dan distributor), Manufacturing (distributor dan pabrik), dan Procurement (pabrik dan penyedia bahan baku). Efisiensi proses yang bermuara ke arah pull yang ditopang oleh e-business berpotensi menghilangkan satu siklus yaitu replenishment cycle. Konsumen dapat meletakkan order dan langsung mendapatkan produk dari pabrik. Dengan hilangnya replenishment cycle, terdapat potensi efisiensi bagi seluruh supply chain, tetapi juga mempunyai dampak negatif karena mengancam pelaku usaha di dalam siklus tersebut, yaitu distributor dan toko [2][3].

Ancaman pada pelaku usaha distributor dan toko selain dikarenakan perkembangan penyediaan barang yang lebih ke arah pull, juga sangat dipengaruhi oleh perkembangan di bidang logistik. Logistik dapat didefinisikan menjadi manajemen perpindahan barang dari supplier hulu sampai ke konsumen hilir [4] maupun komunikasi untuk mengatur aktivitas logistik [5]. Logistik yang didukung oleh teknologi bermetamorfosis menjadi e-logistic. E-logistic merupakan kegiatan pendukung untuk memenuhi permintaan konsumen secara daring, dan atau berbasis teknologi (perangkat lunak, web, mobile, cloud, IoT, block chain, AI). Penggunaan teknologi pada logistik tersebut pada akhirnya akan menghasilkan keunggulan kompetitif dalam supply chain [6], tetapi juga merupakan ancaman bagi pelaku usaha distributor maupun toko karena peran perantara fisik akan digantikan oleh teknologi e-logistic tersebut.

Secara tradisional membangun $e$-logistic secara inhouse membutuhkan sumber daya yang masif. Sumber daya yang masif tersebut di masa lalu menjadi halangan masuk industri/barriers to entry bagi organisasi untuk menerapkan e-logistics. Dengan perkembangan teknologi dan spesialisasi bisnis, biaya implementasi e-logistic menjadi minimal dengan adanya skema outsourcing (3PL/third party logistics) [7][8]. Perusahaan-perusahaan 3PL berfokus membangun infrastruktur dan implementasi teknologi logistik untuk mencapai skala ekonomis dan keunggulan kompetitif. 3PL tersebut kemudian menyewakan infrastruktur/teknologi tersebut kepada organisasi-organisasi yang membutuhkan layanan tersebut. $E$ logistic kini dapat diakses dengan biaya yang sangat minim sehingga perusahaan online/penjual daring skala kecil pun dapat memanfaatkan fasilitas tersebut. Beberapa penyedia layanan 3PL di Indonesia adalah Wira Logistic, Ceva, DHL Supply Chain dan Kamadjaja Logistic, Pos Logistik Indonesia [9].

Dari sektor e-commerce, keunggulan logistik dikembangkan oleh JD.ID dengan membangun gudang masif di beberapa daerah strategis [10]. Dengan gudang-gudang di daerah strategis, produk akan dapat didistribusikan lebih dekat dengan konsumen dan konsumen akan mendapatkan value dari berkurangnya biaya kirim barang, penjual mendapatkan keunggulan dari bertambahnya pesanan. Selain itu, logistik e-commerce yang akan berfungsi seperti $e$-logistic sedang dikembangkan oleh Tokopedia dalam bentuk layanan TokoCabang. Penjual skala kecil dapat memanfaatkan layanan TokoCabang tersebut dengan hanya menitipkan barang di gudang Tokopedia, proses pengemasan dan pengiriman barang bahkan melayani pertanyaan konsumen disediakan oleh Tokopedia [11].

E-logistic yang disediakan 3PL yang dapat dimanfaatkan oleh penjual online skala kecil maupun pabrik skala besar berpotensi mengurangi biaya produk konsumen secara signifikan. Sebagai contoh: biaya transportasi barang dari pulau Jawa ke pulau Kalimantan membutuhkan biaya Rp 35.000 per kilogram melalui udara. Dengan adanya 3PL, biaya transportasi tersebut dapat berkurang menjadi Rp 10.000/hampir $400 \%$ dengan waktu pengiriman lebih pendek. Bagi pabrik, biaya yang hilang dari investasi pada toko fisik dan biaya distribusi melalui distributor juga akan menjadi sebuah penambah value dalam supply chain organisasi yang sangat signifikan [12][13][14]. Penambahan value bagi konsumen akhir maupun pabrik ini di lain pihak akan menjadi ancaman bagi pelaku usaha di siklus replenishment yaitu distributor dan toko.

Oleh karena itu, tujuan dari penelitian ini adalah menyelidiki perkembangan dari SCM dan teknologi e-logistic pada praktiknya di Kalimantan Barat khususnya di Pontianak. Fokus dari penelitian adalah pada menyelidiki dampak ancaman perkembangan SCM dan teknologi $e$-logistic yang disediakan perusahaan 3PL tersebut terhadap pelaku usaha di replenishment cycle yaitu pada distributor. Penelitian akan dibatasi pada industri pakaian jadi karena merupakan salah satu sektor yang terdampak akibat pergeseran gaya belanja dan perkembangan SCM [15]. Dari hasil observasi, industri distributor pakaian jadi berpusat di Pontianak yang merupakan ibukota provinsi, berpusat di kawasan pasar tengah, Pontianak Selatan.

Protection Motivation Theory (PMT) diutilitasi pada penelitian ini. PMT merupakan teori yang dikembangkan oleh Rogers dengan pernyataan bahwa motivasi perubahan sikap seorang individu dipengaruhi oleh rasa takut terhadap kejadian atau pemicu tertentu. Rasa takut tersebut mempunyai tiga komponen utama: (1) Efek dari pemicu; (2) Probabilitas terjadi/efek ancaman dari pemicu; (3) Kemampuan diri dalam menanggapi pemicu [16]. PMT merupakan teori yang dominan pada bidang kesehatan [17], kemudian digunakan sebagai salah satu teori dalam penerimaan teknologi [18]. PMT berfokus pada sisi 
ketakutan yang dirasakan pengguna dan bagaimana mengatasi ketakutan tersebut. Pada dasarnya PMT mengukur bagaimana individu melakukan tindakan tertentu (preventif) berdasarkan analisis cost benefit terhadap ancaman yang dihadapi. Dengan utilisasi teori ini, diharapkan responden dapat menjelaskan dampak dari teknologi di SCM khususnya di e-logistic pada keberlangsungan bisnis responden.

\section{Metode Penelitian}

Metode penelitian yang digunakan untuk mencapai tujuan penelitian adalah deskriptif kualitatif dengan pendekatan studi kasus [19]. Pengumpulan data dilakukan dengan observasi langsung dan wawancara dengan pertanyaan semi terstruktur. Data dikumpulkan dengan mengambil sampel pada populasi distributor pakaian jadi di lingkungan Pontianak Selatan. Pengambilan sampel menggunakan purposive sampling [20], sebanyak 3 pelaku usaha distributor dengan skala berbeda dipilih, di mana ketigatiganya beroperasi pada lokasi yang diteliti. Tiga sampel dinilai cukup oleh peneliti dan diambil dengan pertimbangan tidak mencapai saturation [19]. Data dikumpulkan dengan menggunakan bantuan alat rekam dan disadur ke dalam bentuk teks. Data teks kemudian dianalisis secara kualitatif dengan menggunakan bantuan software NVivo 12.

Belum ada penelitian sebelumnya di daerah Pontianak tentang efek dari SCM maupun -logistic terhadap bisnis secara praktis di siklus replenishment. Peneliti berharap utilitasi teori PMT dapat memberikan penjelasan tentang SCM dari sudut pandang efek negatif dari inovasi. Selain itu, karena belum adanya penelitian sebelumnya dan desain penelitian ini yang bersifat kualitatif, diharapkan muncul penjelasan tambahan dari jawaban responden dan memberikan petunjuk penyesuaian teori yang akan digunakan pada penelitian selanjutnya [19]. Wawancara dan pertanyaan semi terstruktur dilakukan untuk sesuai tujuan penelitian dengan utilisasi teori protection motivation theory oleh Rogers [16]. Daftar pertanyaan terstruktur yang ditanyakan adalah (tabel 1)

Tabel 1. Daftar Pertanyaan Topik Berdasarkan Teori

\begin{tabular}{llll}
\hline \multicolumn{2}{c}{ Efek dari teknologi. } & \multicolumn{1}{c}{ Kerentanan terhadap teknologi } & Kemampuan diri menghadapi pemicu \\
\hline Dengan adanya supply chain & Bagaimana pendapat responden, apakah & Bagaimana persiapan bisnis responden \\
management modern, menurut & SCM maupun teknologi e-logistic akan menanggapi SCM/teknologi e-logistic \\
responden, apakah akan berdampak \\
terhadap bisnis distributor?
\end{tabular}

Pada saat wawancara, pertanyaan lanjutan yang tidak terstruktur ditanyakan sesuai dengan perkembangan wawancara dan arah percakapan. Pertanyaan yang ditanyakan adalah yang berkaitan dengan histori organisasi, rekam jejak, jaringan, operasional, dan teknologi yang digunakan untuk bisnis responden.

\section{Hasil dan Pembahasan}

Responden merupakan distributor pada berbagai tingkat penjualan per bulan. Pada EM yang diberikan kode A mempunyai penjualan mencapai Rp 600 juta per bulan, sedangkan responden MD atau B merupakan responden dengan penjualan terendah dengan jumlah Rp 87 juta per bulan. Responden ketiga atau $\mathrm{C}$ merupakan distributor dengan omzet di antara keduanya dengan jumlah Rp 262,5 juta. Dari ketiga responden, hanya A yang mempunyai merek sendiri dan merupakan distributor dengan jumlah omzet per bulan tertinggi. Responden A juga merupakan distributor dengan daerah jangkauan yang paling luas di antara ketiga responden.

Tabel 2. Profil Responden

\begin{tabular}{lccc}
\hline \multicolumn{1}{c}{ Responden } & $\boldsymbol{E M}(\boldsymbol{A})$ & $\boldsymbol{M D}(\boldsymbol{B})$ & $\boldsymbol{F J}(\boldsymbol{C})$ \\
\hline Jenis Industri & Distributor & Distributor & Distributor \\
\hline Merek Sendiri & Ya & Tidak & Tidak \\
\hline Perkiraan omzet/bulan & $600,000,000$ & $87,000,000$ & $262,500,000$ \\
\hline Umur Pemilik & 62 th & 39 th & 53 th \\
\hline Lama Beroperasi & 37 th & 11 th & 25 th \\
\hline Jumlah toko dalam jaringan & 200 & 40 & 70 \\
\hline & Pontianak, Ketapang, & & \\
Daerah layanan & Landak & Pontianak, & Pontianak, \\
& Sanggau, Sintang, & Ketapang & Landak. \\
& Sambas, Bengkayang \\
& KapuasHulu. & & \\
\hline
\end{tabular}


Pertanyaan semi terstruktur wawancara sesuai teori yang diutilisasi diberikan kode dalam software NVivo dengan struktur topik 1 yaitu efek dari teknologi, topik 2 yaitu kerentanan terhadap teknologi, topik 3 yaitu kemampuan diri menghadapi pemicu. Coding dalam NVivo dapat dilihat pada gambar:

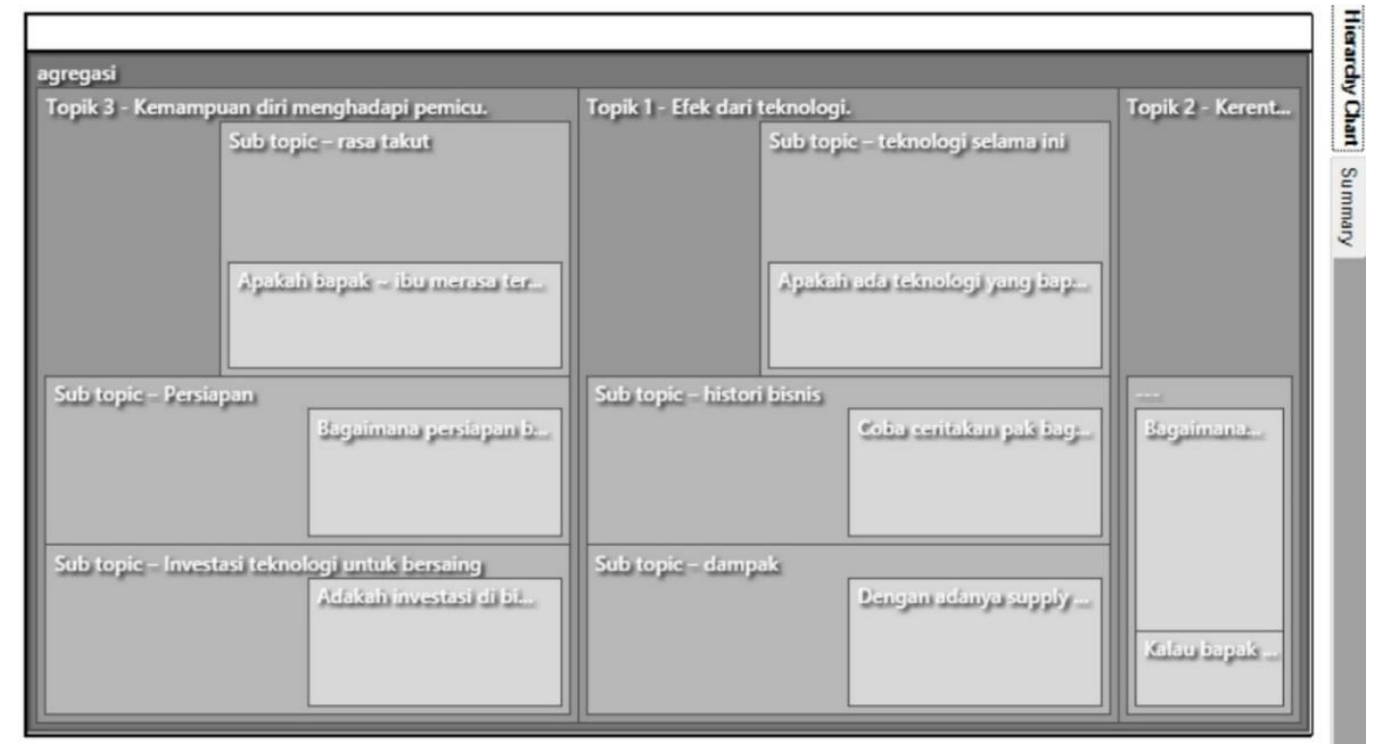

Gambar 1. Coding pertanyaan dalam wawancara.

Coding tersebut berguna untuk melihat struktur pertanyaan dan konten dari wawancara di mana dari hasil dapat terlihat bahwa topik 1 dan topik 3 adalah topik dengan konten terbanyak dari wawancara. Responden memberikan jawaban lebih intensif dalam kedua topik tersebut dibanding topik kedua.

Setelah coding dilakukan, peneliti melakukan word frequency untuk menentukan kata kunci yang berulang di dalam wawancara (Gambar 2). Hasil dari word frequency tersebut dapat dilihat pada gambar. Lima kata yang paling sering berulang dalam wawancara adalah "saya", "yang", "toko", "ada", dan "teknologi". Dua kata utama yang merupakan tema kunci jawaban responden yang dapat dianalisis lebih lanjut adalah "toko" dan "teknologi".

Selanjutnya dilakukan pencarian konteks tema dengan keyword in context, untuk menemukan tema pembahasan responden berdasarkan kata yang paling sering berulang yaitu "toko" dan "teknologi". Hasil pencarian keyword in context dapat dilihat pada Gambar 3 dan 4. Hasil pencarian memberikan konteks bagi tema atau kata kunci. Dari analisis yang dilakukan pada jawaban responden. Alasan kata "toko" menjadi tema dari responden disebabkan oleh usaha distributor yang dikembangkan oleh responden semuanya berawal dari toko eceran.

Ketiga responden mempunyai histori usaha yang mirip di mana usaha distributor responden berasal dari toko eceran. Pada A, usaha distributor yang dilakukan merupakan perkembangan dari toko yang telah dirintis oleh kakak responden. Pada B, usaha distributor merupakan perkembangan dari toko orang tua. Pada C, usaha distributor yang dirintis, berasal dari toko emas orang tua yang beralih menjadi usaha distributor.

Pada tema kedua yaitu "teknologi", setelah dilakukan pencarian keyword in context, memberikan konfirmasi bahwa teknologi merupakan faktor yang dirasakan sebagai ancaman bagi ketiga responden. Ketiga responden menjawab "ya", pada saat ditanyakan apakah perkembangan SCM dan e-logistic akan mengancam bisnis distributor yang dilakukan oleh responden.

Dari penelusuran lebih lanjut, teknologi yang diutilisasi pada jalur distribusi masih terbatas pada telepon biasa dan media komunikasi berbasis web seperti WhatsApp. Dua responden telah menerapkan teknologi berbasis database dan barcode hanya untuk input data dan kode barang, yaitu pada responden A dan B. Responden C masih menggunakan media kertas sebagai pencatat inventory maupun transaksi, walaupun sudah berskala cukup besar.

Setelah penentuan tema selesai, dilakukan analisis untuk pertanyaan utama dari setiap responden. Ringkasan respons dapat dilihat pada Tabel 2 di halaman berikut. Pada topik satu, yaitu efek dari teknologi, responden ditanyakan responsnya terhadap SCM dan teknologi e-logistic. Responden A menganggap SCM sebagai topik baru, tapi sebenarnya konsepnya tidak baru, responsnya adalah "Waduh, saya baru pertama kali dengar tuh tentang itu (SCM dan e-logistic), tapi sebenarnya itu bukan konsep baru”. Responden B 
sudah mengetahui tentang konsep tersebut tapi tidak mengetahui bahwa terdapat istilah khusus yaitu SCM. Responden C merasa SCM dan teknologi e-logistic akan mempengaruhi bisnisnya secara langsung, responsnya adalah "Mungkin iya, lama-lama distributor juga tidak lagi perlu toko, yang penting punya produk. Siapa yang pegang merek siapa yang menang".

Pada topik kedua, yaitu kerentanan terhadap teknologi SCM dan e-logistic. Pertanyaan yang ditanyakan adalah apakah perkembangan SCM dan e-logistic mempengaruhi bisnis. Responden A menganggap SCM dan e-logistic oleh 3PL akan sangat berpengaruh, dan pengaruhnya positif untuk bisnis responden. Responden A mempunyai fasilitas produksi sendiri dengan merek sendiri, dengan adanya 3PL, responden tidak lagi perlu fokus pada pengadaan alat transportasi dan pergudangan. Peniadaan faktor tersebut akan sangat meningkatkan efisiensi operasi bagi responden. Responden menambahkan bahwa selama ini pada distribusi produk untuk bisnisnya selalu mengalami masalah yang tidak dapat diprediksi sebelumnya, seperti sopir mengalami kecelakaan di rute rutin, masalah klaim asuransi yang lama, pemeliharaan armada truk. Komentar akhir yang diberikan oleh responden tentang 3PL adalah "Saya punya banyak karyawan. Dari mengatur banyak karyawan tersebut, saya sadar, selalu ada saja masalah kecil yang nanti jadi besar. Ini jadi pertimbangan saya kalau memang layanan itu sudah ada. Bisa tidak mereka diandalkan? Bagaimana dengan barang yang hilang tengah jalan? Apakah ada asuransi dan sebagainya”.

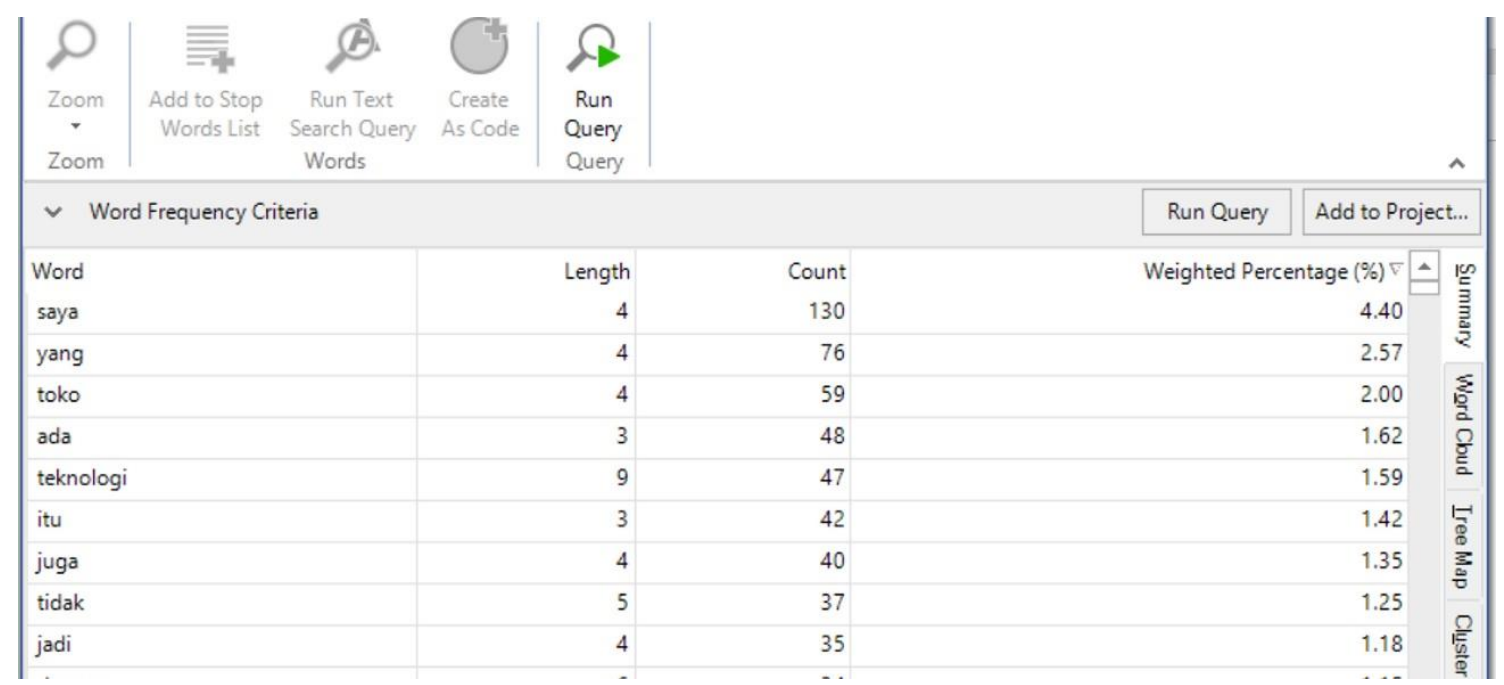

Gambar 2. Hasil olahan pencarian kata kunci tema respons.

Reference $4-0.11 \%$ Coverage

asisten saya. jadi kalau cerita teknologi, saya masih menggunakan telepon biasa

Reference $5-0.11 \%$ Coverage

produksi barang. Kayaknya hanya itu teknologi yang saya terapkan. Oh ya

Reference $6-0.11 \%$ Coverage

ya satu lagi, ini termasuk teknologi atau bukan ya, saya menerapkan

Reference $7-0.11 \%$ Coverage

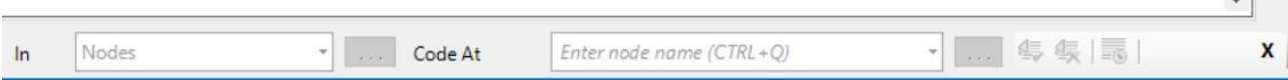

Gambar 3. Hasil olahan konteks kata kunci teknologi. 


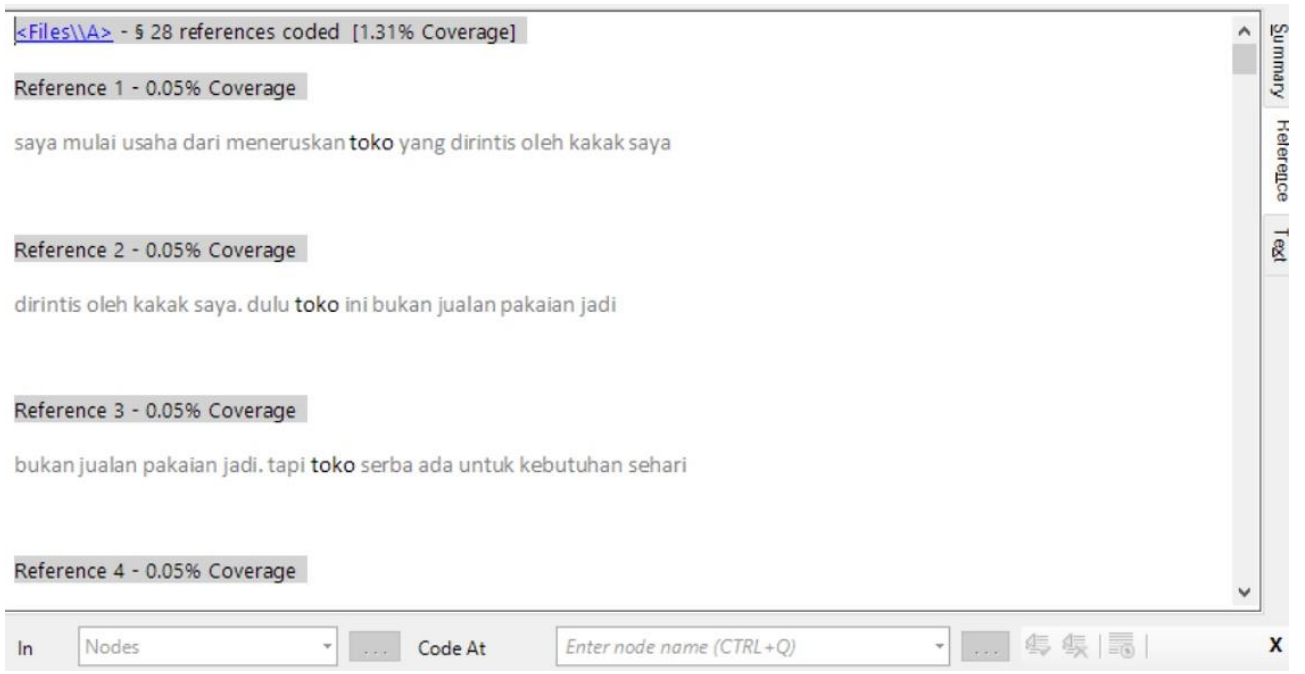

Gambar 4. Hasil olahan konteks kata kunci toko.

Tabel 3. Ringkasan Respons

\begin{tabular}{|c|c|c|c|}
\hline Teori dan Pertanyaan & Responden A & Responden B & Responden C \\
\hline \multicolumn{4}{|l|}{ Efek Dari Teknologi } \\
\hline $\begin{array}{l}\text { Dengan adanya supply chain } \\
\text { management modern, menurut } \\
\text { responden, apakah akan berdampak } \\
\text { terhadap bisnis distributor? }\end{array}$ & $\begin{array}{l}\text { Berdampak, SCM } \\
\text { merupakan topik baru tapi } \\
\text { dengan konsep lama }\end{array}$ & $\begin{array}{l}\text { Berdampak, sudah } \\
\text { mengetahui konsep } \\
\text { distribusi tersebut sejak } \\
\text { dulu, tetapi tidak } \\
\text { mengetahui bahwa ada } \\
\text { istilah khusus untuk itu }\end{array}$ & $\begin{array}{l}\text { Berdampak, merasa } \\
\text { akan mengancam } \\
\text { bisnis terutama karena } \\
\text { tidak mempunyai } \\
\text { merek produksi sendiri }\end{array}$ \\
\hline \multicolumn{4}{|l|}{ Kerentanan Terhadap Teknologi } \\
\hline $\begin{array}{l}\text { Bagaimana pendapat responden, apakah } \\
\text { SCM maupun teknologi e-logistic akan } \\
\text { mempengaruhi bisnis responden? }\end{array}$ & $\begin{array}{l}\text { Sangat mempengaruhi, } \\
\text { menyambut teknologi } \\
\text { tersebut karena akan } \\
\text { meringankan beberapa } \\
\text { proses bisnis dan efisiensi } \\
\text { jalur distribusi }\end{array}$ & $\begin{array}{l}\text { Ancaman nyata, merek } \\
\text { yang didistribusikan } \\
\text { selama ini akan dapat } \\
\text { digantikan secara mudah } \\
\text { oleh produsen bahkan } \\
\text { pesaing. Selama ini } \\
\text { mengandalkan mahalnya } \\
\text { biaya kirim }\end{array}$ & $\begin{array}{l}\text { Berdampak pada } \\
\text { bisnis, tetapi tidak } \\
\text { dalam jangka waktu } \\
\text { dekat }\end{array}$ \\
\hline \multicolumn{4}{|l|}{ Kemampuan Menghadapi Pemicu } \\
\hline $\begin{array}{l}\text { Bagaimana persiapan bisnis responden } \\
\text { menanggapi SCM/teknologi e-logistic } \\
\text { baru tersebut? }\end{array}$ & $\begin{array}{l}\text { Terancam, persiapan } \\
\text { dengan memperkuat } \\
\text { merek, dan mengutilisasi } \\
\text { penuh relasi yang telah } \\
\text { dibangun }\end{array}$ & $\begin{array}{l}\text { Terancam, persiapan } \\
\text { dengan upaya menciptakan } \\
\text { manufaktur produk dengan } \\
\text { merek sendiri }\end{array}$ & $\begin{array}{l}\text { Terancam, akan keluar } \\
\text { dari industri apabila } \\
\text { tidak ada penerus }\end{array}$ \\
\hline
\end{tabular}

Pada responden $\mathrm{B}$, perkembangan SCM dan teknologi e-logistic merupakan sebuah ancaman nyata. Respons yang diberikan adalah "Ke depannya saya rasa akan sangat pengaruh ya, karena bisa saja merek yang saya jual itu pemiliknya ikutan 3PL. Bahkan konsumen saya yang toko (reseller) juga mungkin akan tidak laku. Konsumen akhir bisa langsung order melalui internet, Tokopedia misalnya, trus barangnya langsung diantar dengan biaya kirim yang murah. Selama ongkos kirimnya mahal, toko masih bisa jualan, karena konsumen akhir berat di ongkir". Responden B mempunyai pendapat negatif tentang e-logistic yang disediakan 3PL. Responden B mengandalkan mahalnya biaya pengiriman yang dialami oleh konsumen sebagai salah satu faktor keunggulan kompetitif penjualan.

Pada responden $\mathrm{C}$, respons yang diberikan selaras dengan responden lainnya, bahwa teknologi $e$ logistic akan berpengaruh terhadap bisnis, hanya saja belum terjadi dalam waktu dekat. Responsnya adalah "Mungkin ke depannya akan pengaruh, sekarang masih belum. Rata-rata toko yang saya pasarkan itu keluarga atau relasi keluarga, jadi faktor kepercayaan dan relasi di sini sangat penting. Toko-toko yang jadi konsumen saya mungkin ditawari juga oleh distributor lain, tapi belum tentu mau ambil barangnya". Responden $\mathrm{C}$ menganggap bisnis responden masih cukup kompetitif karena faktor lain selain SCM dan $e$ logistic sehingga dampak dari perkembangan SCM tersebut mungkin tidak akan terjadi dalam waktu dekat pada bisnisnya. 
Berdasarkan jawaban responden, peneliti mengkonfirmasi bahwa sudah terjadi triangulasi [21], yaitu SCM dan teknologi e-logistic memang mempunyai dampak terhadap bisnis distributor. Semua responden setuju bahwa SCM dan $e$-logistic akan berdampak terhadap model bisnis responden saat ini dan diperlukan tindak lanjut untuk mengatasi dampak tersebut.

Pada topik ketiga, yaitu bagaimana kemampuan diri menghadapi pemicu. Ketiga responden memberikan konfirmasi bahwa mereka merasa terancam dengan perkembangan SCM dan e-logistic. Persiapan responden menghadapi ancaman yang dirasakan berbeda satu sama lain, tetapi triangulasi tercapai pada metode mengatasi ancaman tersebut adalah dengan "merek" dan "relasi".

Respons yang diberikan oleh responden A pada saat peneliti menanyakan bagaimana persiapan untuk menghadapi perkembangan SCM (topik 3) adalah "Merek dan Relasi. hanya dua kata itu yang saya kembangkan dari dulu. Merek saya semua sudah pakai. Bukan sombong. Ke depannya saya akan melebarkan jalur distribusi mungkin ke Kalimantan Tengah, kemudian ke Kalimantan Timur, itu gambaran besarnya. Saya kuat di pelosok-pelosok karena medannya yang berat bagi pendatang baru. Kemudian relasi toko yang saya bangun akan tetap saya pertahankan. Hal kecil, seperti ingat ulang tahun anak konsumen, bonus penjualan. Saat order dilayani dengan ramah, pokoknya mereka adalah relasi yang berharga. Tidak boleh dikecewakan. Satu kali kecewakan, misalnya barang reject atau antar tidak tepat waktu, itu sudah sangat merugikan. Saya sangat peduli dengan relasi”.

Pada responden $\mathrm{B}$, respons yang diberikan adalah "Ya, memang online ini menciptakan kesempatan/ancaman baru, tapi kami sebisa mungkin bersiap sebelum terkena masalah. Kami perlu mengembangkan merek sendiri. Persaingan sekarang sudah sangat ketat sekali apalagi untuk distributor. Kami semua beroperasi dengan margin minimal, dan masih harus menanggung biaya piutang. Karena kami sistem piutang dengan konsumen. Kami berikan barangnya, tagihnya 1-6 bulan kemudian. Karena itu juga, konsumen kami sebenarnya lebih setia dibanding yang beli cash. Ancaman dari teknologi pasti ada. Tapi bisnis distribusi kami masih mengandalkan face-to-face. Toko langganan juga lebih suka ketemu sales langsung daripada foto di WhatsApp. Barangnya bisa dicek fisik langsung. Saat kami juga jualan online yang kirim ke daerah-daerah, kami banyak kirim lewat ekspedisi lokal daripada yang nasional. Kami akan siap menghadapi perubahan".

Pada responden $\mathrm{C}$, respons yang diberikan adalah "Ya, saya rasa nanti bisnis akan semakin sulit, sekarang aja toko online sudah mulai ada dampak. Sebenarnya saya tidak mikir terlalu jauh. Mungkin kalau sudah tidak bisa lagi, saya banting setir ke bisnis lain. Mungkin anak yang teruskan atau mungkin pelanpelan saya alihkan ke bisnis lain. Kalau secara umum, menurut saya supaya bisa tetap bertahan di bisnis distribusi seperti ini adalah relasi. Barang boleh sama, tapi dijual oleh orang yang beda mungkin juga jumlah penjualannya beda. Selain itu, kalau untuk persiapan saya rasa bisa dengan kembangkan produksi (merek) sendiri. Produksi sendiri, mungkin akan lebih bertahan daripada hanya menjadi penyalur merek orang lain. Kalaupun menjadi penyalur, perlu ada kontrak supaya orang lain tidak bisa ikut jual".

Rasa takut merupakan motivator yang kuat untuk perubahan sikap [16]. Rasa takut dipandang sebagai kondisi emosional yang diperlukan untuk mengganggu proses kognitif, sehingga membuat individu memperhatikan pesan yang disampaikan. Rasa takut juga memberikan pesan yang tidak dapat diabaikan oleh penerima pesan sehingga dengan tingkat ketakutan tertentu, perubahan sikap dapat terjadi [22].

Dasar teori Protection Motivation Theory yang digunakan dalam penelitian ini, bahwa rasa takut mendorong objek penelitian melakukan tindakan preventif terhadap perubahan SCM dan teknologi $e$ logistic terbukti secara kualitatif melalui metode triangulasi [21]. Dapat disimpulkan bahwa distributor di dalam replenishment cycle memang terdampak perubahan SCM dan teknologi e-logistic. Ketakutan yang dirasakan oleh pelaku usaha dalam cycle tersebut akan mempengaruhi bagaimana pelaku bisnis menjalankan model bisnis mereka di masa depan. Namun, ketakutan tersebut mempunyai dampak yang berbeda pada tiap responden yang merupakan organisasi UKM. Bagi organisasi A dan B, organisasi tersebut menanggapi rasa takut dengan berevolusi dan pada akhirnya akan menerima perubahan SCM dan teknologi e-logistic dengan terus mempertahankan keunggulan kompetitif. Bagi organisasi C, rasa takut akan diatasi dengan berubah total atau keluar dari industri.

Pelaku usaha yang menjadi responden penelitian merupakan UKM berbasis bisnis keluarga. Atas dasar tersebut dan melihat kata kunci pada tema jawaban responden adalah "toko", dapat ditarik kesimpulan bahwa distributor berevolusi dari sebuah toko yang berkembang dengan dasar dan manajemen bisnis keluarga. Toko merupakan titik terbawah dari sebuah rantai pasok barang yang berhubungan langsung dengan konsumen. Toko kemudian berkembang menjadi distributor, dan karena tekanan faktor eksternal seperti perkembangan SCM maupun teknologi, terus berkembang lagi menjadi pabrik dengan jalur distribusi masing-masing. Evolusi dari toko menjadi distributor dan akhirnya menjadi pabrik menunjukkan ketangguhan (resilience) dari responden/pelaku usaha. Ketangguhan meliputi kemampuan adaptasi, 
kemampuan responsif, ketahanan dan keunggulan di pasar yang dilayani. Ketangguhan merupakan faktor kritis untuk terus berkembang di era globalisasi [23].

Responden penelitian menunjukkan ketangguhan UKM pada 2 faktor yaitu penggunaan teknologi dan lokasi/pemasaran dari 4 faktor penting (penciptaan modal, penggunaan teknologi, integrasi supply chain, dan lokasi/pemasaran) seperti yang disarankan oleh Gunasekaran pada studi terdahulu [23]. Penggunaan teknologi akan dipicu dari rasa takut yang mendorong evolusi organisasi dan akhirnya menerima perubahan teknologi. Hadirnya e-logistic mendorong organisasi berubah dan akhirnya akan menerima teknologi tersebut sebagai unsur keunggulan kompetitif. Sedangkan lokasi/pemasaran akan dipicu dari unsur merek dan relasi.

Dari jawaban responden, merek menjadi kunci utama yang diperlukan dari ketiga organisasi distributor pada penelitian. Merek yang dimaksud di sini tidak terbatas pada faktor terkenal atau tidaknya merek tersebut, melainkan bagaimana merek dapat digunakan untuk mengunci keunggulan kompetitif distributor. Dengan adanya merek sendiri yang terkunci secara eksklusif pada distributor, organisasi menjadi lebih kompetitif dalam memasarkan produk, sehingga perubahan jaman dan teknologi yang terjadi dalam bisnis distribusi akan menjadi katalis mencapai keunggulan daripada mematikan. Dengan mempunyai merek sendiri, teknologi e-logistic yang ditawarkan oleh 3PL bahkan akan diterima dengan baik karena distributor tidak lagi perlu mengeluarkan biaya besar untuk mengembangkan e-logistic sendiri. Temuan tersebut mendukung temuan studi sebelumnya tentang bagaimana menciptakan merek sendiri merupakan strategi kunci untuk mencapai keunggulan kompetitif di rantai produk busana [24].

Selain merek, faktor pemasaran penting bagi distributor adalah relasi. Hubungan relasi yang dimaksud responden selaras dengan penelitian sebelumnya [23][25] tentang UKM berbasis bisnis keluarga. Hubungan dekat kerabat keluarga merupakan salah satu faktor internalisasi yang penting untuk kendali yang lebih baik dalam supply chain. Internalisasi tersebut akan menutup pihak luar untuk ikut masuk ke industri sehingga tercipta barriers of entry yang akan mendukung keunggulan kompetitif distributor.

Perkembangan atau evolusi bisnis pada organisasi tersebut di satu pihak menunjukkan ketangguhan pemilik usaha, tetapi juga menunjukkan bahwa kooperasi dalam supply chain masih belum terjadi. Setiap unit bisnis berusaha mengembangkan jalur supply dan pabrik sendiri daripada bekerja sama dengan unit bisnis lain dalam industri yang sama. Dalam SCM, keengganan berkooperasi tersebut merupakan biaya yang besar dan salah satu alasan mengapa supply chain bersangkutan akan kurang kompetitif [2]. Kelemahan tersebut juga selaras dengan studi sebelumnya di negara lain di mana pelaku dalam supply chain khususnya UKM enggan berkooperasi dengan entitas bisnis lain dalam supply chain yang sama [26].

Fenomena lain dalam SCM yang berhasil digali dari penelitian ini adalah dari segi drivers di pricing, dan transportation [2]. Kedua faktor tersebut merupakan drivers dari supply chain yang akan menentukan keunggulan kompetitif sebuah supply chain. Responden A yang mempunyai fasilitas produksi menerapkan satu harga standar di sepanjang jalur distribusi organisasi dan harga standar tersebut menjadi salah satu sumber keunggulan kompetitif responden selama hampir 40 tahun beroperasi. Informasi tersebut memberikan konfirmasi bahwa pricing merupakan drivers yang kuat dalam membangun keunggulan kompetitif sebuah supply chain. Pada penelitian lanjutan, dapat digali lebih lanjut bagaimana diskon dan pemberian harga dapat mempengaruhi efisiensi maupun efektivitas supply chain. Dari driver transportasi, walaupun 3PL dan e-logistic yang berkembang saat ini menawarkan kemudahan manajerial dan efisiensi biaya, faktor infrastruktur yang masih belum berkembang tetap merupakan penghalang utama. Jalan-jalan fisik yang bahkan tidak ada di pelosok-pelosok daerah Kalimantan menjadi salah satu penghalang utama dan sekaligus sebagai sebuah unsur keunggulan bagi organisasi tertentu yang dapat digali lebih lanjut pada penelitian selanjutnya. Pemerintah mempunyai andil penuh dalam hal infrastruktur. Walaupun teknologi sudah berkembang, komunikasi di pelosok masih tetap mengandalkan metode lama karena keterbatasan infrastruktur. Fakta tersebut menjadi konfirmasi pentingnya penetrasi internet dan pembangunan infrastruktur terutama di pelosok Kalimantan Barat. Selain itu, pihak pendidikan akan menjadi pelaku penting dalam membantu UKM berevolusi beriringan dengan teknologi karena UKM dapat meminimalisir risiko teknologi dengan penelitian-penelitian yang dilakukan pihak pendidikan.

\section{Kesimpulan}

Perkembangan SCM dipandang sebagai ancaman bagi pelaku usaha replenishment cycle pada industri busana di Pontianak Selatan. Teori PMT yang diutilisasi penelitian memberikan beberapa kesimpulan, yaitu ancaman tersebut merupakan katalis bagi penerimaan teknologi. Ancaman diantisipasi dengan mengupayakan manufaktur untuk produk organisasi. Ancaman diantisipasi dengan mempertahankan keunggulan melalui utilisasi merek dan relasi yang telah dibangun selama organisasi beroperasi. Ancaman tersebut juga menjadi alasan keluar dari industri. 
Beberapa kesimpulan tambahan yang berhasil digali dari penelitian adalah kooperasi inter organisasi untuk mencapai efisiensi supply chain masih belum menjadi unsur penting pada industri. Driver SCM yaitu pricing dan transportation sudah dipraktikkan secara parsial oleh pelaku dalam industri untuk mencapai keunggulan kompetitif.

Hasil penelitian karena bersifat kualitatif, maka dapat dikembangkan lebih lanjut pada penelitian lanjutan dengan menguji bagaimana SCM dan teknologi mempengaruhi secara kuantitatif dengan sampel yang lebih representatif. Dari hasil penelitian, beberapa teori yang dapat digali lebih lanjut pada penelitian lanjutan adalah suksesi dalam bisnis keluarga, drivers pada supply chain, barriers of entry dengan internalisasi pada jaringan supply chain, maupun exit strategy korporasi dalam bereaksi terhadap tekanan eksternal.

\section{Daftar Pustaka}

[1] E. Monk and B. Wagner, Concepts in Enterprise Resource Planning, 4th ed. New York: CENGage, 2012.

[2] S. Chopra and P. Meindl, Supply Chain Management. Strategy, Planning \& Operation, 5th ed. New York: Pearson/Prentice Hall, 2013.

[3] W. M. Lankford, "Supply chain management and the Internet," Online Inf. Rev., vol. 28, no. 4, pp. 301-305, 2004, doi: 10.1108/14684520410553796.

[4] D. Waters, Supply Chain Management: An Introduction to Logistics, 2nd ed. New York: Red Globe Press, 2009.

[5] Y. Wang and S. Pettit, "E-Logistics: Managing Your Digital Supply Chains for Competitive Advantage," Procedia CIRP, vol. 52, pp. 179-185, 2016.

[6] Y. Yu, X. Wang, R. Y. Zhong, and G. Q. Huang, "E-commerce Logistics in Supply Chain Management: Practice Perspective," Procedia CIRP, vol. 52, pp. 179-185, 2016, doi: 10.1016/j.procir.2016.08.002.

[7] L. Fadile, M. El Oumami, and Z. Beidouri, "Logistics outsourcing: A review of basic concepts," Int. J. Supply Chain Manag., vol. 7, no. 3, pp. 53-69, 2018.

[8] J. Yang and K. Yu, "The role of an integrated logistics and procurement service offered by a 3PL firm in supply chain," J. Manag. Anal., vol. 6, no. 1, pp. 49-66, 2019, doi: 10.1080/23270012.2019.1568921.

[9] Logisticbid, "Perusahaan Logistik 3PL: Kamadjaja Logistics, Agility, Ceva, DB Schenker, Deliveree, Puninar, Pancaran Group," 2020, [Online]. Available: https://logisticsbid.com/perusahaan-logistik3pl-kamadjaja-logistics-agility-ceva-db-schenker-puninar-pancaran-group/.

[10] D. Syarizka, “Order Makin Besar, JD.ID Tambah Kapasitas Gudang Logistik,” 2019. https://teknologi.bisnis.com/read/20190315/266/900289/order-makin-besar-jd.id-tambah-kapasitasgudang-logistik.

[11] Tokopedia, "Akselerasi Pemerataan Ekonomi Secara Digital, Tokopedia Luncurkan Layanan Gudang Pintar 'TokoCabang,"” 2019. https://www.tokopedia.com/blog/press-release-tokopedia-luncurkanlayanan-gudang-pintar-tokocabang/.

[12] J. Zou and L. Shan, "3PL-HUB supply chain logistics cost simulation study based on system dynamics," Adv. Mater. Res., vol. 779, pp. 1752-1757, 2013, doi: 10.4028/www.scientific.net/AMR.779-780.1752.

[13] R. Rajesh, S. Pugazhendhi, K. Ganesh, C. Muralidharan, and R. Sathiamoorthy, "Influence of 3PL service offerings on client performance in India," Transp. Res. Part E Logist. Transp. Rev., vol. 47, no. 2, pp. 149-165, 2011, doi: 10.1016/j.tre.2010.09.008.

[14] K. Tezuka, "Rationale for utilizing 3PL in supply chain management: A shippers' economic perspective," IATSS Res., vol. 35, no. 1, pp. 24-29, 2011, doi: 10.1016/j.iatssr.2011.07.001.

[15] A. P. Situmorang, "Menko Darmin Beberkan Penyebab Banyaknya Usaha Ritel Bangkrut," 2019. https://www.merdeka.com/uang/menko-darmin-beberkan-penyebab-banyaknya-usaha-ritelbangkrut.html.

[16] J. E. Maddux and R. W. Rogers, "Protection motivation and self-efficacy: A revised theory of fear appeals and attitude change," J. Exp. Soc. Psychol., vol. 19, no. 5, pp. 469-479, 1983, doi: 10.1016/0022-1031(83)90023-9.

[17] D. L. Floyd, S. Prentice-dunn, and R. W. Rogers, "A Meta-Analysis of Research on Protection Motivation Theory," J. Appl. Soc. Psychol., vol. 30, no. 2, pp. 407-429, 2000.

[18] T. Sommestad, H. Karlzén, and J. Hallberg, "A meta-Analysis of studies on protection motivation theory and information security behaviour," Int. J. Inf. Secur. Priv., vol. 9, no. 1, pp. 26-46, 2015, doi: 10.4018/IJISP.2015010102. 
[19] J. W. Creswell, Research Design, Qualitative, Quantitative, and Mixed Methods Approaches, 4th ed. London: Sage Publishing, 2014.

[20] U. Sekaran and R. Bougie, Research Methods for Business, 7th ed. West Sussex: Wiley, 2016.

[21] W. Olsen, "Triangulation in Social Research: Qualitative and Quantitative Methods Can Really Be Mixed," in Developments in Sociology, M. Holborn, Ed. Ormskirk: Causeway Press, 2004, p. 30.

[22] T. M. Welbourne, "Fear: A Misunderstood Component of Organizational Transformation," Cent. Adv. Hum. Resour. Stud., vol. 94, no. 11, pp. 1-19, 1994.

[23] A. Gunasekaran, B. K. Rai, and M. Griffin, "Resilience and competitiveness of small and medium size enterprises: An empirical research," Int. J. Prod. Res., vol. 49, no. 18, pp. 5489-5509, 2011, doi: 10.1080/00207543.2011.563831.

[24] T. Urakami and X. Wu, "Own brand strategy of the Japanese apparel manufacturers," Asia Pacific J. Mark. Logist., vol. 29, no. 1, pp. 114-128, 2017, doi: 10.1108/APJML-12-2015-0189.

[25] H. W. C. Yeung, "Limits to the Growth of Family-Owned Business? The Case of Chinese Transnational Corporations from Hong Kong," Fam. Bus. Rev., vol. 13, no. 1, pp. 55-70, 2000, doi: 10.1111/j.1741-6248.2000.00055.x.

[26] Y. Krykavskyy and N. Hayvanovych, "Competitiveness of Family SMEs in the Supply Chain," J. Intercult. Manag., vol. 11, pp. 81-103, 2019, doi: 10.2478/joim-2019-0004. 